\title{
Biological role, clinical significance, and therapeutic possibilities of the recently discovered metabolic hormone fibroblastic growth factor 21
}

\author{
Pedro Iglesias, Rafael Selgas ${ }^{1}$, Sara Romero ${ }^{2}$ and Juan J Díez \\ Department of Endocrinology, Hospital Ramón y Cajal, Ctra. de colmenar, Km 9,100, 28034 Madrid, Spain, ${ }^{1}$ Department of Nephrology, Hospital \\ Universitario La Paz, IdiPAZ, Madrid, Spain and ${ }^{2}$ Department of Nephrology, Hospital de Arganda, Madrid, Spain \\ (Correspondence should be addressed to P Iglesias; Email: piglo65@gmail.com)
}

\begin{abstract}
Fibroblast growth factor 21 (FGF21), a 181 amino acid circulating protein, is a member of the FGF superfamily, with relevant metabolic actions. It acts through the interaction with specific FGF receptors and a cofactor called $\beta$-Klotho, whose expression is predominantly detected in metabolically active organs. FGF21 stimulates glucose uptake in adipocytes via the induction of glucose transporter-1. This action is additive and independent of insulin. $\beta$-Cell function and survival are preserved, and glucagon secretion is reduced by this protein, thus decreasing hepatic glucose production and improving insulin sensitivity. Lipid profile has been shown to be improved by FGF21 in several animal models. FGF21 increases energy expenditure in rodents and induces weight loss in diabetic nonhuman primates. It also exerts favorable effects on hepatic steatosis and reduces tissue lipid content in rodents. Adaptive metabolic responses to fasting, including stimulation of ketogenesis and fatty acid oxidation, seem to be partially mediated by FGF21. In humans, serum FGF21 concentrations have been found elevated in insulin-resistant states, such as impaired glucose tolerance and type 2 diabetes. FGF21 levels are correlated with hepatic insulin resistance index, fasting blood glucose, HbAlc, and blood glucose after an oral glucose tolerance test. A relationship between FGF21 levels and long-term diabetic complications, such as nephropathy and carotid atheromatosis, has been reported. FGF21 levels decreased in diabetic patients after starting therapy with insulin or oral agents. Increased FGF21 serum levels have also been found to be associated with obesity. In children, it is correlated with BMI and leptin levels, whereas in adults, FGF21 levels are mainly related to several components of the metabolic syndrome. Serum FGF21 levels have been found to be elevated in patients with ischemic heart disease. In patients with renal disease, FGF21 levels exhibited a progressive increase as renal function deteriorates. Circulating FGF21 levels seem to be related to insulin resistance and inflammation in dialysis patients. In summary, FGF21 is a recently identified hormone with antihyperglycemic, antihyperlipidemic, and thermogenic properties. Direct or indirect potentiation of its effects might be a potential therapeutic target in insulin-resistant states.
\end{abstract}

European Journal of Endocrinology 167 301-309

\section{Introduction}

Human fibroblast growth factor 21 (FGF21) is a 181 amino acid $(\sim 20 \mathrm{kDa})$ circulating protein derived from a 209-amino acid mature protein encoded by the FGF21 gene located in chromosome 19 (1, 2). FGF21 belongs to the human FGF superfamily, initially named by its ability to stimulate fibroblast proliferation, which contains 22 proteins (3). The FGF gene family can be divided into three subfamilies: the intracellular FGFs (FGF11/12/13/14), the endocrine FGFs (FGF15/19/ $21 / 23)$, and the paracrine FGFs (the rest) $(3,4,5)$. FGFs bind extracellularly to four cell surface tyrosine kinase FGF receptors (FGFRs 1-4) $(6,7,8,9)$.
The amino acid sequence of human FGF21 is highly identical ( $\sim 75 \%$ amino acid identity) to that of mouse FGF21. FGF21 mRNA is preferentially expressed not only in the liver but also in other tissues, such as white adipose tissue (WAT), skeletal muscle, and pancreas $(1,10,11,12)$. FGF21 is detected in plasma, suggesting that it is secreted into circulation acting as a true hormone. FGF21 activity depends on its binding to FGFRs and a cofactor called $\beta$-Klotho, a single-pass transmembrane protein whose expression is induced during differentiation from preadipocytes to adipocytes. The cofactor $\beta$-Klotho is predominantly expressed in metabolic organs including liver, WAT, and pancreas (13). This cofactor is crucial for the FGF21 specificity of 
the target cells increasing the ability of FGFRs to bind FGF21 (14, 15). The FGF21- $\beta$-Klotho-FGFR complex acts by inducing MAP kinase phosphorylation in WAT (14). FGF21 expression is controlled by different transcriptional factors such as peroxisome proliferator-activated receptor $\alpha(\operatorname{PPAR} \alpha(P P A R A))$ in the liver $(16,17)$ and PPAR $\gamma(P P A R G)$ in adipocytes $(18)$.

The purpose of this review has been to update the most relevant aspects of FGF2 1 focusing on its biological role and clinical significance, as well as its possible role as a potential therapeutic agent in human disease.

\section{Biological roles of FGF21: animal studies}

FGF21 has been recently considered as a metabolic hormone regulated by nutritional status with multiple beneficial effects on glucose homeostasis and lipid metabolism in animal models. Indeed, FGF21 improves insulin sensitivity, glucose, and lipid homeostasis and preserves $\beta$-cell functions in diabetic animal models $(11,19,20,21,22,23,24)$ (Table 1). Furthermore, unlike the majority of the members of the FGF family, FGF21 is free of the proliferative and tumorigenic effects $(11,19,25)$.

\section{Glucose and insulin metabolism}

FGF21, through its binding to $\beta$-Klotho-FGFR complex, stimulates glucose uptake in differentiated adipocytes via the induction of glucose transporter-1 (GLUT1) through sequential activation of transcription factors, requiring several hours for this activity $(19,26,27)$ (Fig. 1). Glucose uptake induced by FGF21 is additive and independent of insulin. This glucose entry into adipocytes results in its storage as triglyceride (TG). Moreover, the ability of FGF21 for increasing the thermogenic capacity of WAT could, at least in part, lead to a greater clearance of glucose $(17,28)$.

FGF21 might also act on glucagon metabolism and vice versa. FGF21 suppresses hepatic glucose production, increases liver glycogen, and lowers glucagon in mice (29). On the other hand, hepatic expression of PPAR $\alpha$ and FGF21 is stimulated by hepatic glucagon

Table 1 Metabolic effects of FGF21 in animal models.

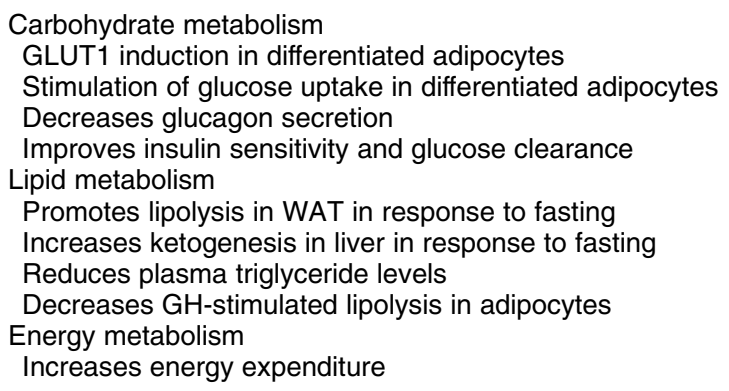

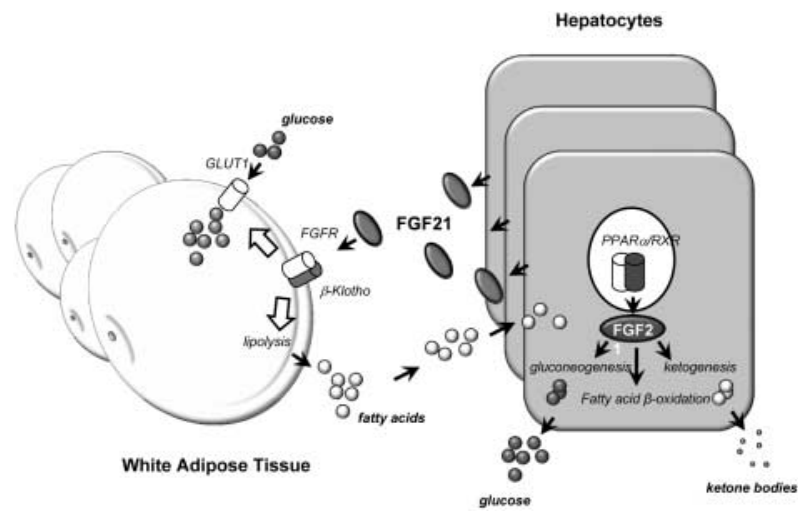

Figure 1 Effects of FGF21 on adipocytes and hepatocytes in animal models. i) FGF21 binds to its receptor FGFR and the cofactor $\beta$-Klotho stimulating glucose uptake in differentiated adipocytes via GLUT1 induction. ii) Fasting induces both hepatic expression and circulating levels of FGF21 which promotes lipolysis in adipocytes and ketogenesis and gluconeogenesis in liver directly induced by PPAR $\alpha$.

receptor activation in a manner that is further augmented by fatty acids (30). It has also been reported that FGF21 preserves $\beta$-cell function and survival by activation of extracellular signal-regulated kinase 1/2 and Akt signaling pathways (11).

All these actions would be associated with a reduction of blood glucose. Indeed, systemic administration of FGF21 has shown to reduce plasma glucose to near normal levels in genetically compromised diabetic rodents (19) and fasting plasma glucose, fructosamine, insulin, and glucagon without developing hypoglycemia in diabetic rhesus monkeys $(20,31)$. Lastly, continuous i.c.v. infusion of FGF21 in high-fat diet-induced obese (DIO) male Wistar rats increased hepatic insulin sensitivity due to increased insulin-induced suppression of both hepatic glucose production and gluconeogenic gene expression indicating the central nervous system (CNS) as a potentially important target for the beneficial effects of FGF21 (23). In fact, FGF21 has shown to have a significant, nonsaturable, unidirectional influx across the blood-brain barrier (32).

\section{Lipid metabolism}

FGF21 has shown beneficial effects on lipid profile in animal models. Systemic administration of FGF21 was also followed by a decrease in plasma TG, free fatty acids (FFA), and cholesterol in genetically compromised diabetic and obese rodents $(19,31)$. Moreover, FGF21 administration also induces changes in the mRNA profiles of several genes involved in lipid metabolism in DIO mice (21). In WAT, FGF21 increased mRNA levels of uncoupling protein 1 (UCP1), PPAR $\gamma$ coactivator $1 \alpha$ (PGC1 $\alpha$ ), hormone-sensitive lipase (HSL), and adipose TG lipase (ATGL), whereas in brown adipose tissue (BAT), FGF21 administration led to an elevation of 
UCP1 and acetyl-coenzyme A (CoA) carboxylases 2 (ACC2) transcripts (21). In diabetic rhesus monkeys, chronic FGF21 therapy significantly improved lipid profile, including a decrease in TG and LDL and an increase in HDL (20).

\section{Obesity}

FGF21 also seems to be involved in the regulation of body fat mass. Circulating FGF21 concentrations are significantly elevated in obesity (33) in rodents responding poorly to exogenous FGF21, indicating that obesity could be an FGF21-resistant state (34). FGF21 increases energy expenditure in mice with free access to food, thereby correcting obesity $(21,31)$, and transgenic mice overexpressing FGF21 have shown to be resistant to diet-induced metabolic abnormalities and obesity (19). A small but significant weight loss was also reported after chronic FGF21 therapy in diabetic nonhuman primates (20). These antiobesity actions of FGF21 appear to be mediated by an increase in energy expenditure and preferential fat utilization because weight loss is accompanied by elevated oxygen consumption, increased core body temperature in the absence of decrease in total caloric intake, or effect on physical activity $(21,31)$. Moreover, FGF21 enhances the expression of genes involved in thermogenesis within brown fat increasing body temperature (17).

\section{Hepatic steatosis}

In addition to correcting multiple metabolic alterations, FGF21 reverses hepatic steatosis and decreases tissue (muscle and BAT) lipid contents in DIO mice (31). This favorable effect on hepatic steatosis might be related to the inhibition of the maturation of sterol regulatory element-binding protein-1c, a transcription nuclear factor that activates all genes required for lipogenesis $(31,35)$.

\section{Adaptive response to fasting}

A link between FGF21 and fasting in animals has been reported. The adaptive response to fasting seems to be mediated by the activation of PPAR $\alpha$, a nuclear receptor activated by fatty acids, which leads to stimulation of gluconeogenesis, ketogenesis, and fatty acid oxidation $(36,37)$. These metabolic responses of PPAR $\alpha$ to fasting are mainly mediated by FGF21 (19, 37, 38, 39). Several observations support this statement: i) PPAR $\alpha$ agonist therapy, low-carbohydrate ketogenic diet and fasting induce hepatic expression, and circulating levels of FGF21 that are rapidly suppressed by refeeding (16); ii) FGF21 regulates fasting promoting lipolysis in WAT from murine adipocytes and ketogenesis in liver in response to fasting directly induced by PPAR $\alpha$ (22, 36, 37), although this FGF21-induced lipolysis has not been demonstrated by others (40, 41); iii) knockdown of FGF21 in the liver results in impaired ketogenesis and fatty acid oxidation in mice (16); iv) FGF21 reduces physical activity and promotes torpor in mice, a short-term hibernation state with the aim of saving energy by reducing physical activity and body temperature energy (37); and v) FGF21-overexpressing transgenic mice show reduced fat mass and resistance to obesity $(19,38,39)$. These findings would demonstrate a role for the PPAR $\alpha$-FGF21 endocrine signaling pathway in regulating diverse metabolic and behavioral aspects of the adaptive response to starvation (Fig. 1). The opposite effects of FGF21 on glucose metabolism might depend on several factors such as nutritional status, fasting or feeding, and normal or altered glucose metabolism.

\section{Other effects}

It is known that GH and FGF21 are metabolic hormones involved in the regulation of glucose and lipid metabolism. Both hormones are induced in response to fasting and act on adipocytes promoting lipolysis. The existence of a possible feedback loop between $\mathrm{GH}$ and FGF21 has recently been documented $(42,43)$. GH induces hepatic production of FGF21 by activation of the transcription factor PPAR $\alpha$ through FFA released from adipose tissue by GH-induced lipolysis, and elevated FGF21, in turn, acts as a negative feedback signal to terminate GH-stimulated lipolysis in adipocytes (42). These effects suggest that FGF21 and GH might act in a coordinated way to control the amplitude and duration of lipolysis during adaptive response to fasting (42).

FGF21 has proved capable of inhibiting apoptosis in cultured cardiac endothelial cells from male adult Wistar rats and might play physiological roles in improving the endothelial function at an early stage of atherosclerosis and in stopping the development of coronary heart disease (CHD) (44).

\section{FGF21 in health and human disease}

In humans, FGF21 is mainly produced not only in liver and adipose tissue but also in skeletal muscle and thymus $(1,45,46)$. The contribution from each tissue to plasma is not known. Several recent studies have analyzed circulating FGF21 levels in communitydwelling adults (47), as well as its role related to diabetes, insulin resistance, metabolic syndrome (MetS), nonalcoholic fatty liver disease (NAFLD), and weight status in humans $(45,47,48,49,50,51,52$, 53, 54, 55) (Table 2).

The normal reference range for FGF21 varies considerably among different studies. For example, the median (interquartile range) morning fasting serum FGF21 concentration was 468 (295-520) pg/ml in a group of 50 healthy subjects (50), whereas it was 
Table 2 Clinical significance of FGF21 in human disease.

Insulin resistance and diabetes
Connection between high serum FGF21 levels and abnormal
glucose metabolism and insulin resistance in community-dwelling
adults
Association between elevated circulating FGF21 levels and insulin
resistance, impaired glucose tolerance and type 2 diabetes, but
not to type 1 diabetes, and LADA
Relationship between FGF21 and diabetes complications in type 2
diabetes (DM2)
Diabetic nephropathy: positive correlation with urinary albumin
excretion
Diabetic macroangiopathy: elevated FGF21 levels in DM2
patients with carotid artery plaques
Obesity
Increased serum FGF21 levels in children and adults with obesity
Positive correlation between FGF21 and BMI, leptin, and FFA in
children
Independent marker for the presence of MetS in obesity in adults
Independent predictor of liver steatosis
FGF21 increases after weight loss induced by short-term VLCD
CHD
FGF21 levels are increased in CHD
Higher FGF21 in CHD patients with metabolic comorbidities
(diabetes, hypertension, or both)
Chronic renal disease
Independent association of FGF21 with renal function
Progressive increment of FGF21 from early- to end-stage CKD

FFA, free fatty acids; MetS, metabolic syndrome; VLCD, very low calorie diet CHD, coronary heart disease; CKD, chronic kidney disease; LADA, latent autoimmune diabetes in adults.

$225(126-370) \mathrm{pg} / \mathrm{ml}$ in a cohort study of aging in community-dwelling men and women (47). On the other hand, 24-h profiles of serum FGF21 concentration have shown various oscillation patterns ranging from 6 to 12 times per day, with an average oscillation duration of about $2.5 \mathrm{~h}$ and without circadian rhythm, suggesting that FGF21 may be secreted into systemic circulation in a pulsatile manner (56). However, other authors have documented a circadian rhythm of FGF21 during fasting in both obese and lean individuals $(57,58,59)$, and it has been suggested that it could be caused by the oscillation of FFA (59). Lastly, FGF21 increases in healthy subjects only after a 7-day fast, supporting the hypothesis that FGF21 is induced by prolonged fasting in humans as also occurs in mice (57).

\section{FGF21, insulin resistance, and type 2 diabetes}

Increased serum FGF21 concentrations have been recently associated with abnormal glucose metabolism and insulin resistance in community-dwelling adults (47). In this regard, circulating FGF21 concentrations have been found elevated in insulin-resistant states, such as impaired glucose tolerance and type 2 diabetes (DM2) $(45,48,49,50,51,60)$ but decreased in type 1 diabetes and latent autoimmune diabetes in adults (61). FGF21 was also an independent predictor of DM2 in humans and its elevation is independent of the DM2 duration (62). Lastly, FGF21 seems to be also independently associated with markers of insulin resistance and an adverse lipid profile in polycystic ovary syndrome (63) and gestational diabetes (64).

FGF21 correlates inversely with insulin sensitivity at muscle level and directly with the hepatic insulin resistance index, fasting plasma glucose, and 2-h plasma glucose after an oral glucose tolerance test and $\mathrm{HbA} 1 \mathrm{c}$, indicating a clear relationship with hepatic and wholebody insulin resistance in DM2 $(48,49,62,65)$. In addition, FGF21 is expressed in human skeletal muscle in response to insulin stimulation, suggesting that FGF21 is an insulin-regulated myokine (46).

The role of insulin on FGF21 is currently not well understood. Some studies have shown that artificial hyperinsulinemia performed in healthy subjects is accompanied by an increase in FGF21 levels (66). However, it has also been reported that FGF21 also increases in hypoinsulinemic states (67). This discrepancy might be in relation to an elevation of stimulators of FGF21 secretion such as FFAs, resulting from complete insulin deficiency (66). Therefore, FGF21 responses to insulin might be affected by several confounders, such as obesity, endogenous circulating FFAs, insulin levels, and insulin resistance.

FGF21 has direct effects in enhancing skeletal muscle glucose uptake, providing additional points of regulation that may contribute to the beneficial effects of FGF21 on glucose homeostasis (60). On the other hand, several other studies on humans have reported that FGF21 inhibits lipolysis in adipocytes, indicating that the antilipolytic effect could be a mechanism through which FGF 21 promotes insulin sensitivity in man (40).

Several studies have linked high levels of FGF21 with the presence of chronic complications associated with diabetes (50). In fact, serum FGF21 level was independently correlated with urinary albumin excretion in a group of DM2 patients, indicating that circulating FGF21 may be involved in diabetic nephropathy. Moreover, serum FGF21 levels were significantly higher in the DM2 subjects with carotid artery plaques compared with those without plaque (51).

In relation to therapy of diabetes, the addition of rosiglitazone (68) or pioglitazone and exenatide (69) on ongoing metformin therapy in DM2 patients as well as the use of mitiglinide (70) or short-term continuous s.c. insulin infusion (71) in patients with newly diagnosed DM2 was followed by a significant reduction in circulating FGF21 levels suggesting that FGF21 decreases as insulin sensitivity improves. Based on all these observations, FGF21 should be considered as a new hormone with a significant role in insulin-resistant states and complications associated with DM2, possibly promoting insulin sensitivity in man as a compensatory mechanism (Fig. 2). 


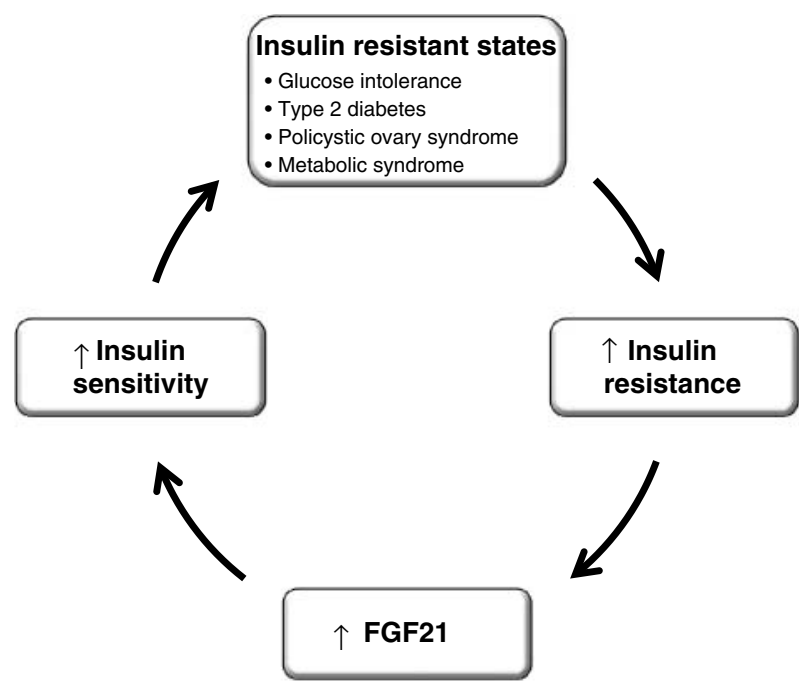

Figure 2 Hypothetical model of relationship between FGF21 and insulin-resistant states as an insulin resistance compensator in humans.

\section{FGF21 and obesity}

It has recently been reported that human FGF 21 gene expression is paradoxically and independently regulated by both fasting and feeding signals, suggesting that human FGF21 is increased with nutritional crisis, including starvation and overfeeding (72).

Increased FGF21 serum levels have been found to be associated with obesity in both children (52) and adults $(45,53,54)$, indicating a connection between FGF21 and body fat mass.

Obesity in childhood not only has shown to be associated with increased FGF21 serum levels compared with normal-weight children but also a positive correlation between FGF21 and FFA was established (52). This observation is important due to the fact that FFA have been defined as physiological stimulators of FGF21 secretion (66).

Although it has been reported that FGF21 is significantly correlated to BMI and leptin as markers of WAT in children (52), this fact does not always occur in adults. In this case, several metabolic alterations such as high liver fat, TG, insulin, homeostasis model assessment (HOMA) index, and area under the curve of glucose and lower HDL rather than overall adiposity have been associated with high FGF21 levels (73). Therefore, FGF21 seems to be an independent marker for the presence of MetS in obesity $(53,73,74)$. Indeed, serum FGF21 level has also been reported to be significantly increased and positively correlated with intrahepatic TG content in NAFLD, representing an independent predictor of liver steatosis $(54,75,76,77)$.

Studies that have analyzed the response of FGF21 to weight loss in humans have shown controversial findings. On the one hand, FGF21 significantly increased after weight loss induced by short-term (3 weeks) very low calorie diet (VLCD) (45). These results are in concordance with those obtained in mice after fasting, indicating a possible response of FGF21 to fasting after PPAR $\alpha$ activation $(37,45)$, suggesting that FGF21 might be related to the improvement in insulin sensitivity associated with weight loss induced by VLCD in obese patients (45). However, on the other hand, FGF21 levels were not modified by moderate weight reduction $(\sim 5 \mathrm{~kg})$ after a 6 -month weight loss program based on hypocaloric diet and physical activity in a group of 30 obese subjects (78). Moreover, significant weight loss associated with bariatric surgery in 23 nondiabetic morbidly obese patients did not modify serum FGF21 levels over time (79).

On the contrary, plasma FGF21 concentrations have been found to be decreased in patients with anorexia nervosa (AN) compared with normal-weight healthy women. FGF21 has also significantly correlated with serum levels of leptin, adiponectin, and insulin in both the normal-weight women and the severely underweight patients with $\mathrm{AN}$ and significantly reduced after 2 months of realimentation (80). Further clinical studies focused on alterations in circulating levels of FGF21 linked to changes in body weight in both obesity and low weight are necessary.

\section{FGF21 and cardiovascular disease}

A relationship between FGF21 and CHD has recently been reported. In a clinic-based study, median serum FGF21 levels were significantly higher in CHD patients than in control subjects. Moreover, CHD patients with diabetes, hypertension, or both showed higher FGF21 levels than those of patients without these comorbidities (55). In this study, FGF21 levels correlated positively with TG, fasting blood glucose, apolipoprotein B100, insulin, and HOMA index of insulin resistance (HOMA-IR) but negatively with HDL and apolipoprotein $\mathrm{A} 1$, indicating a positive association between FGF21 and adverse lipid profile in CHD patients and a possible compensatory response or resistance to FGF21 (55).

\section{FGF21 and renal disease}

Circulating FGF21 levels are independently associated with renal function and progressively increased from early- to end-stage renal disease (ESRD) $(81,82,83,84)$. Compared with healthy subjects, serum FGF21 levels have been found to be $\sim 8-15$ times higher in long-term dialysis patients $(81,82)$. It has been suggested that FGF21 mighty play a role in insulin resistance in patients with ESRD (82). Indeed, FGF21 was positively correlated with inflammatory markers (interleukin-6, fibrinogen, and high-sensitivity C-reactive protein) and HOMA-IR and negatively with residual renal function in a group of 72 nondiabetic peritoneal dialysis patients (82). 
Impaired renal excretion combined with compensatory mechanisms to counteract metabolic stress and/or insulin resistance and FGF21 resistance in peripheral tissues might explain the marked elevation of serum FGF21 concentration in dialysis patients $(81,82)$.

\section{Potential therapeutic applications}

Evidence reported so far suggests that FGF21 possesses favorable metabolic effects not only on carbohydrate but also on lipid metabolism showing antihyperglycemic and antihyperlipidemic properties promoting insulin sensitivity and thermogenesis. In humans, high FGF21 levels have been invariably linked to insulin-resistant states, such as glucose intolerance, DM2, MetS, and obesity, as well as some of their complications such as CHD, indicating a possible compensatory elevation of FGF21 to overcome insulin resistance. Based on the previous studies, as it has been suggested by some authors, FGF21 represents a novel and attractive therapeutic agent. In this regard, the pharmacological use of recombinant human FGF21, FGF21 analogs or agonists, and drugs that increase circulation levels of endogenous FGF21 might be of interest in the therapeutic armamentarium against disease states associated with insulin resistance, mainly DM2, obesity, polycystic ovary syndrome, and hepatic steatosis $(21,85,86,87,88,89,90)$. Further investigations in patients with the above-mentioned states and other metabolic disorders associated with insulin resistance are, therefore, required to clarify the true role of the potential therapeutic applications of this new metabolic hormone.

\section{Declaration of interest}

The authors declare that there is no conflict of interest that could be perceived as prejudicing the impartiality of the research reported.

\section{Funding}

This research did not receive any specific grant from any funding agency in the public, commercial, or not-for-profit sector.

\section{References}

1 Nishimura T, Nakatake Y, Konishi M \& Itoh N. Identification of a novel FGF, FGF-21, preferentially expressed in the liver. Biochimica et Biophysica Acta 20001492 203-206. (doi:10.1016/S01674781(00)00067-1)

2 FGF21 fibroblast growth factor 21 (Homo sapiens), Gene ID: 26291, Updated on, 25-Mar-2012. 2012.

3 Long YC \& Kharitonenkov A. Hormone-like fibroblast growth factors and metabolic regulation. Biochimica et Biophysica Acta 20111812 791-795. (doi:10.1016/j.bbadis.2011.04.002)

4 Itoh $\mathrm{N} \&$ Ornitz DM. Functional evolutionary history of the mouse fgf gene family. Developmental Dynamics 2008237 18-27. (doi:10.1002/dvdy.21388)

5 Kuro-o M. Endocrine FGFs and klothos: emerging concepts. Trends in Endocrinology and Metabolism 200819 239-245. (doi:10.1016/ j.tem.2008.06.002)
6 Ornitz DM, Xu J, Colvin JS, McEwen DG, MacArthur CA, Coulier F, Gao G \& Goldfarb M. Receptor specificity of the fibroblast growth factor family. Journal of Biological Chemistry 1996271 1529215297. (doi:10.1074/jbc.271.25.15292)

7 Zhang X, Ibrahimi OA, Olsen SK, Umemori H, Mohammadi M \& Ornitz DM. Receptor specificity of the fibroblast growth factor family: the complete mammalian FGF family. Journal of Biological Chemistry $2006 \mathbf{2 8 1}$ 15694-15700. (doi:10.1074/jbc.M6012 52200)

8 Krejci P, Prochazkova J, Bryja V, Kozubik A \& Wilcox WR. Molecular pathology of the fibroblast growth factor family. Human Mutation 200930 1245-1255. (doi:10.1002/humu.21067)

9 Beenken A \& Mohammadi M. The FGF family: biology, pathophysiology and therapy. Nature Reviews Drug Discovery 20098 235-253. (doi:10.1038/nrd2792)

10 Muise ES, Azzolina B, Kuo DW, El-Sherbeini M, Tan Y, Yuan X, $\mathrm{Mu}$ J, Thompson JR, Berger JP \& Wong KK. Adipose fibroblast growth factor 21 is up-regulated by peroxisome proliferatoractivated receptor gamma and altered metabolic states. Molecular Pharmacology $2008 \quad 74 \quad 403-412$. (doi:10.1124/mol.108. 044826)

11 Wente W, Efanov AM, Brenner M, Kharitonenkov A, Koster A, Sandusky GE, Sewing S, Treinies I, Zitzer H \& Gromada J. Fibroblast growth factor- 21 improves pancreatic $\beta$-cell function and survival by activation of extracellular signal-regulated kinase $1 / 2$ and akt signaling pathways. Diabetes 200655 2470-2478. (doi:10.2337/db05-1435)

12 Johnson CL, Weston JY, Chadi SA, Fazio EN, Huff MW, Kharitonenkov A, Köester A \& Pin CL. Fibroblast growth factor 21 reduces the severity of cerulein-induced pancreatitis in mice. Gastroenterology 2009137 1795-1804. (doi:10.1053/j.gastro. 2009.07.064)

13 Ito S, Kinoshita S, Shiraishi N, Nakagawa S, Sekine S, Fujimori T \& Nabeshima YI. Molecular cloning and expression analyses of mouse $\beta$ klotho, which encodes a novel klotho family protein. Mechanisms of Development 200098 115-119. (doi:10.1016/ S0925-4773(00)00439-1)

14 Ogawa Y, Kurosu H, Yamamoto M, Nandi A, Rosenblatt KP, Goetz R, Eliseenkova AV, Mohammadi M \& Kuro-o M. $\beta$ Klotho is required for metabolic activity of fibroblast growth factor 21 . PNAS 2007104 7432-7437. (doi:10.1073/pnas.0701600104)

15 Suzuki M, Uehara Y, Motomura-Matsuzaka K, Oki J, Koyama Y, Kimura M, Asada M, Komi-Kuramochi A, Oka S \& Imamura T. $\beta$ Klotho is required for fibroblast growth factor (FGF) 21 signaling through FGF receptor (FGFR) 1c and FGFR3c. Molecular Endocrinology 200822 1006-1014. (doi:10.1210/me.20070313)

16 Badman MK, Pissios P, Kennedy AR, Koukos G, Flier JS \& MaratosFlier E. Hepatic fibroblast growth factor 21 is regulated by PPAR $\alpha$ and is a key mediator of hepatic lipid metabolism in ketotic states. Cell Metabolism 20075 426-437. (doi:10.1016/j.cmet.2007.05. 002)

17 Hondares E, Rosell M, Gonzalez FJ, Giralt M, Iglesias R \& Villarroya F. Hepatic FGF21 expression is induced at birth via $\mathrm{PPAR} \alpha$ in response to milk intake and contributes to thermogenic activation of neonatal brown fat. Cell Metabolism $2010 \mathbf{1 1}$ 206-212. (doi:10.1016/j.cmet.2010.02.001)

18 Wang H, Qiang L \& Farmer SR. Identification of a domain within peroxisome proliferator-activated receptor gamma regulating expression of a group of genes containing fibroblast growth factor 21 that are selectively repressed by SIRT1 in adipocytes. Molecular and Cellular Biology $2008 \mathbf{2 8}$ 188-200. (doi:10.1128/MCB. 00992-07)

19 Kharitonenkov A, Shiyanova TL, Koester A, Ford AM, Micanovic R, Galbreath EJ, Sandusky GE, Hammond LJ, Moyers JS, Owens RA, Gromada J, Brozinick JT, Hawkins ED, Wroblewski VJ, Li DS, Mehrbod F, Jaskunas SR \& Shanafelt AB. FGF-21 as a novel metabolic regulator. Journal of Clinical Investigation 2005115 1627-1635. (doi:10.1172/JCI23606)

20 Kharitonenkov A, Wroblewski VJ, Koester A, Chen YF, Clutinger CK, Tigno XT, Hansen BC, Shanafelt AB \& Etgen GJ. 
The metabolic state of diabetic monkeys is regulated by fibroblast growth factor-21. Endocrinology $2007 \mathbf{1 4 8} 774-781$. (doi:10.1210/en.2006-1168)

21 Coskun T, Bina HA, Schneider MA, Dunbar JD, Hu CC, Chen Y, Moller DE \& Kharitonenkov A. Fibroblast growth factor 21 corrects obesity in mice. Endocrinology 2008149 6018-6027. (doi:10.1210/en.2008-0816)

22 Hotta Y, Nakamura H, Konishi M, Murata Y, Takagi H, Matsumura S, Inoue K, Fushiki T \& Itoh N. Fibroblast growth factor 21 regulates lipolysis in white adipose tissue but is not required for ketogenesis and triglyceride clearance in liver. Endocrinology 2009150 4625-4633. (doi:10.1210/en.20090119)

23 Sarruf DA, Thaler JP, Morton GJ, German J, Fischer JD, Ogimoto K \& Schwartz MW. Fibroblast growth factor 21 action in the brain increases energy expenditure and insulin sensitivity in obese rats. Diabetes 201059 1817-1824. (doi:10.2337/db09-1878)

24 Kralisch S \& Fasshauer M. Fibroblast growth factor 21: effects on carbohydrate and lipid metabolism in health and disease. Current Opinion in Clinical Nutrition and Metabolic Care 201114 354-359. (doi:10.1097/MCO.0b013e328346a326)

25 Huang X, Yu C, Jin C, Yang C, Xie R, Cao D, Wang F \& McKeehan WL. Forced expression of hepatocyte-specific fibroblast growth factor 21 delays initiation of chemically induced hepatocarcinogenesis. Molecular Carcinogenesis 200645934 942. (doi:10.1002/mc.20241)

26 Li K, Li L, Yang M, Liu H, Boden G \& Yang G. The effects of fibroblast growth factor-21 knockdown and over-expression on its signaling pathway and glucose-lipid metabolism in vitro. Molecular and Cellular Endocrinology 2012348 21-26. (doi:10.1016/j.mce. 2011.07.026)

27 Ge X, Chen C, Hui X, Wang Y, Lam KS \& Xu A. Fibroblast growth factor 21 induces glucose transporter-1 expression through activation of the serum response factor/Ets-like protein-1 in adipocytes. Journal of Biological Chemistry 201128634533 34541. (doi:10.1074/jbc.M111.248591)

28 Fisher FM, Kleiner S, Douris N, Fox EC, Mepani RJ, Verdeguer F, Wu J, Kharitonenkov A, Flier JS, Maratos-Flier E \& Spiegelman BM. FGF21 regulates PGC- $1 \alpha$ and browning of white adipose tissues in adaptive thermogenesis. Genes and Development $201226271-$ 281. (doi:10.1101/gad.177857.111)

29 Berglund ED, Li CY, Bina HA, Lynes SE, Michael MD, Shanafelt AB, Kharitonenkov A \& Wasserman DH. Fibroblast growth factor 21 controls glycemia via regulation of hepatic glucose flux and insulin sensitivity. Endocrinology 2009150 4084-4093. (doi:10.1210/en.2009-0221)

30 Berglund ED, Kang L, Lee-Young RS, Hasenour CM, Lustig DG, Lynes SE, Donahue EP, Swift LL, Charron MJ \& Wasserman DH. Glucagon and lipid interactions in the regulation of hepatic AMPK signaling and expression of PPAR $\alpha$ and FGF21 transcripts in vivo. American Journal of Physiology Endocrinology and Metabolism 2010 299 E607-E614. (doi:10.1152/ajpendo.00263.2010)

$31 \mathrm{Xu} \mathrm{J}$, Lloyd DJ, Hale C, Stanislaus S, Chen M, Sivits G, Vonderfecht S, Hecht R, Li YS, Lindberg RA, Chen JL, Jung DY, Zhang Z, Ko HJ, Kim JK \& Veniant MM. Fibroblast growth factor 21 reverses hepatic steatosis, increases energy expenditure, and improves insulin sensitivity in diet-induced obese mice. Diabetes 200958 250-259. (doi:10.2337/db08-0392)

32 Hsuchou H, Pan W \& Kastin AJ. The fasting polypeptide FGF21 can enter brain from blood. Peptides 200728 2382-2386. (doi:10.1016/j.peptides.2007.10.007)

33 Hale C, Chen MM, Stanislaus S, Chinookoswong N, Hager T, Wang M, Veniant MM \& Xu J. Lack of overt FGF21 resistance in two mouse models of obesity and insulin resistance. Endocrinology 2012153 69-80. (doi:10.1210/en.2010-1262)

34 Fisher FM, Chui PC, Antonellis PJ, Bina HA, Kharitonenkov A, Flier JS \& Maratos-Flier E. Obesity is a fibroblast growth factor 21 (FGF21)-resistant state. Diabetes $2010 \quad \mathbf{5 9} \quad 2781-2789$. (doi:10.2337/db10-0193)
35 Browning JD \& Horton JD. Molecular mediators of hepatic steatosis and liver injury. Journal of Clinical Investigation 2004 114 147-152. (doi:10.1172/JCI200422422)

36 Kersten S, Seydoux J, Peters JM, Gonzalez FJ, Desvergne B \& Wahli W. Peroxisome proliferator-activated receptor $\alpha$ mediates the adaptive response to fasting. Journal of Clinical Investigation 1999103 1489-1498. (doi:10.1172/JCI6223)

37 Inagaki T, Dutchak P, Zhao G, Ding X, Gautron L, Parameswara V, Li Y, Goetz R, Mohammadi M, Esser V, Elmquist JK, Gerard RD, Burgess SC, Hammer RE, Mangelsdorf DJ \& Kliewer SA. Endocrine regulation of the fasting response by PPAR $\alpha$-mediated induction of fibroblast growth factor 21. Cell Metabolism 20075 415-425. (doi:10.1016/j.cmet.2007.05.003)

38 Kurosu H \& Kuro-O M. The klotho gene family as a regulator of endocrine fibroblast growth factors. Molecular and Cellular Endocrinology 2009299 72-78. (doi:10.1016/j.mce.2008.10. 052)

39 Kurosu H \& Kuro-O M. Endocrine fibroblast growth factors as regulators of metabolic homeostasis. BioFactors 200935 52-60. (doi:10.1002/biof.12)

40 Arner P, Pettersson A, Mitchell PJ, Dunbar JD, Kharitonenkov A \& Ryden M. FGF21 attenuates lipolysis in human adipocytes - a possible link to improved insulin sensitivity. FEBS Letters 2008 582 1725-1730. (doi:10.1016/j.febslet.2008.04.038)

41 Li X, Ge H, Weiszmann J, Hecht R, Li YS, Véniant MM, Xu J, Wu X, Lindberg R \& Li Y. Inhibition of lipolysis may contribute to the acute regulation of plasma FFA and glucose by FGF21 in ob/ob mice. FEBS Letters 2009583 3230-3234. (doi:10.1016/j.febslet. 2009.09.012)

42 Chen W, Hoo RL, Konishi M, Itoh N, Lee PC, Ye HY, Lam KS \& $\mathrm{Xu}$ A. Growth hormone induces hepatic production of fibroblast growth factor 21 through a mechanism dependent on lipolysis in adipocytes. Journal of Biological Chemistry 2011286 3455934566. (doi:10.1074/jbc.M111.285965)

43 Yu J, Zhao H, Wang A, Eleswarapu S, Ge X, Chen D \& Jiang H. Growth hormone stimulates transcription of the fibroblast growth factor 21 gene in the liver through the signal transducer and activator of transcription 5. Endocrinology 2012153 750-758. (doi:10.1210/en.2011-1591)

44 Lu Y, Liu JH, Zhang LK, DU J, Zeng XJ, Hao G, Huang J, Zhao DH, Wang GZ \& Zhang YC. Fibroblast growth factor 21 as a possible endogenous factor inhibits apoptosis in cardiac endothelial cells. Chinese Medical Journal 2010123 3417-3421. (doi:10.3760/ cma.j.issn.0366-6999.2010.23.008)

45 Mraz M, Bartlova M, Lacinova Z, Michalsky D, Kasalicky M, Haluzikova D, Matoulek M, Dostalova I, Humenanska V \& Haluzik M. Serum concentrations and tissue expression of a novel endocrine regulator fibroblast growth factor- 21 in patients with type 2 diabetes and obesity. Clinical Endocrinology 200971 369-375. (doi:10.1111/j.1365-2265.2008.03502.x)

46 Hojman P, Pedersen M, Nielsen AR, Krogh-Madsen R, Yfanti C, Akerstrom T, Nielsen S \& Pedersen BK. Fibroblast growth factor21 is induced in human skeletal muscles by hyperinsulinemia. Diabetes 200958 2797-2801. (doi:10.2337/db09-0713)

47 Semba RD, Sun K, Egan JM, Crasto C, Carlson OD \& Ferrucci L. Relationship of serum fibroblast growth factor 21 with abnormal glucose metabolism and insulin resistance: the Baltimore Longitudinal Study of Aging. Journal of Clinical Endocrinology and Metabolism 201297 1375-1382. (doi:10.1210/jc.2011-2823)

48 Chen WW, Li L, Yang GY, Li K, Qi XY, Zhu W, Tang Y, Liu H \& Boden G. Circulating FGF-21 levels in normal subjects and in newly diagnose patients with type 2 diabetes mellitus. Experimental and Clinical Endocrinology \& Diabetes 2008116 65-68. (doi:10.1055/s-2007-985148)

49 Chavez AO, Molina-Carrion M, Abdul-Ghani MA, Folli F, Defronzo RA \& Tripathy D. Circulating fibroblast growth factor21 is elevated in impaired glucose tolerance and type 2 diabetes and correlates with muscle and hepatic insulin resistance. Diabetes Care 200932 1542-1546. (doi:10.2337/dc09-0684)

50 Jian WX, Peng WH, Jin J, Chen XR, Fang WJ, Wang WX, Qin L, Dong Y \& Su Q. Association between serum fibroblast growth 
factor 21 and diabetic nephropathy. Metabolism: Clinical and Experimental 201261 853-859. (doi:10.1016/j.metabol.2011. 10.012)

51 An SY, Lee MS, Yi SA, Ha ES, Han SJ, Kim HJ, Kim DJ \& Lee KW. Serum fibroblast growth factor 21 was elevated in subjects with type 2 diabetes mellitus and was associated with the presence of carotid artery plaques. Diabetes Research and Clinical Practice 2012 96 196-203. (doi:10.1016/j.diabres.2012.01.004)

52 Reinehr T, Woelfle J, Wunsch R \& Roth CL. Fibroblast growth factor 21 (FGF-21) and its relation to obesity, metabolic syndrome, and nonalcoholic fatty liver in children: a longitudinal analysis. Journal of Clinical Endocrinology and Metabolism 201297 2143-2150. (doi:10.1210/jc.2012-1221)

53 Zhang X, Yeung DC, Karpisek M, Stejskal D, Zhou ZG, Liu F, Wong RL, Chow WS, Tso AW, Lam KS \& Xu A. Serum FGF21 levels are increased in obesity and are independently associated with the metabolic syndrome in humans. Diabetes 200857 1246-1253. (doi:10.2337/db07-1476)

54 Dushay J, Chui PC, Gopalakrishnan GS, Varela-Rey M, Crawley M, Fisher FM, Badman MK, Martinez-Chantar ML \& Maratos-Flier E. Increased fibroblast growth factor 21 in obesity and nonalcoholic fatty liver disease. Gastroenterology $2010 \quad 139 \quad 456-463$. (doi:10.1053/j.gastro.2010.04.054)

55 Lin Z, Wu Z, Yin X, Liu Y, Yan X, Lin S, Xiao J, Wang X, Feng W \& Li X. Serum levels of FGF-21 are increased in coronary heart disease patients and are independently associated with adverse lipid profile. PLoS ONE 20105 e15534. (doi:10.1371/journal. pone.0015534)

56 Lee SA, Jeong E, Kim EH, Shin MS, Hwang JY, Koh EH, Lee WJ, Park JY \& Kim MS. Various oscillation patterns of serum fibroblast growth factor 21 concentrations in healthy volunteers. Diabetes $\mathcal{E}$ Metabolism Journal 201236 29-36. (doi:10.4093/dmj.2012.36. 1.29)

57 Gälman C, Lundasen T, Kharitonenkov A, Bina HA, Eriksson M, Hafstrom I, Dahlin M, Amark P, Angelin B \& Rudling M. The circulating metabolic regulator FGF21 is induced by prolonged fasting and PPAR $\alpha$ activation in man. Cell Metabolism 20088 169-174. (doi:10.1016/j.cmet.2008.06.014)

58 Andersen B, Beck-Nielsen H \& Højlund K. Plasma FGF21 displays a circadian rhythm during a 72-h fast in healthy female volunteers. Clinical Endocrinology 201175 514-519. (doi:10.1111/j.1365-2265.2011.04084.x)

59 Yu H, Xia F, Lam KS, Wang Y, Bao Y, Zhang J, Gu Y, Zhou P, Lu J, Jia W \& Xu A. Circadian rhythm of circulating fibroblast growth factor 21 is related to diurnal changes in fatty acids in humans. Clinical Chemistry 201157 691-700. (doi:10.1373/clinchem. 2010.155184)

60 Mashili FL, Austin RL, Deshmukh AS, Fritz T, Caidahl K, Bergdahl K, Zierath JR, Chibalin AV, Moller DE, Kharitonenkov A \& Krook A. Direct effects of FGF21 on glucose uptake in human skeletal muscle: implications for type 2 diabetes and obesity. Diabetes/Metabolism Research and Reviews 201127 286-297. (doi:10.1002/dmrr.1177)

61 Xiao Y, Xu A, Law LS, Chen C, Li H, Li X, Yang L, Liu S, Zhou Z \& Lam KS. Distinct changes in serum fibroblast growth factor 21 levels in different subtypes of diabetes. Journal of Clinical Endocrinology and Metabolism 201297 E54-E58. (doi:10.1210/ jc.2011-1930)

62 Cheng X, Zhu B, Jiang F \& Fan H. Serum FGF-21 levels in type 2 diabetic patients. Endocrine Research 201136 142-148. (doi:10. 3109/07435800.2011.558550)

63 Gorar S, Culha C, Uc ZA, Dellal FD, Serter R, Aral S \& Aral Y. Serum fibroblast growth factor 21 levels in polycystic ovary syndrome. Gynecological Endocrinology 2010 26 819-826. (doi:10.3109/09513590.2010.487587)

64 Stein S, Stepan H, Kratzsch J, Verlohren M, Verlohren HJ, Drynda K, Lossner U, Bluher M, Stumvoll M \& Fasshauer M. Serum fibroblast growth factor 21 levels in gestational diabetes mellitus in relation to insulin resistance and dyslipidemia. Metabolism: Clinical and Experimental $2010 \quad \mathbf{5 9} \quad 33-37$. (doi:10.1016/j.metabol.2009.07.003)
65 Li L, Yang G, Ning H, Yang M, Liu H \& Chen W. Plasma FGF-21 levels in type 2 diabetic patients with ketosis. Diabetes Research and Clinical Practice $2008 \mathbf{8 2}$ 209-213. (doi:10.1016/j.diabres.2008. 07.012)

66 Mai K. Andres J. Biedasek K. Weicht J, Bobbert T, Sabath M, Meinus S, Reinecke F, Mohlig M, Weickert MO, Clemenz M, Pfeiffer AF, Kintscher U, Spuler S \& Spranger J. Free fatty acids link metabolism and regulation of the insulin-sensitizing fibroblast growth factor- 21 . Diabetes 200958 1532-1538. (doi:10.2337/db08-1775)

67 Mai K, Bobbert T, Groth C, Assmann A, Meinus S, Kraatz J, Andres J, Arafat AM, Pfeiffer AF, Möhlig M \& Spranger J. Physiological modulation of circulating FGF21: relevance of free fatty acids and insulin. American Journal of Physiology. Endocrinology and Metabolism 2010299 E126-E130. (doi:10.1152/ ajpendo.00020.2010)

68 Li K, Li L, Yang M, Zong H. Liu H \& Yang G. Effects of rosiglitazone on fasting plasma fibroblast growth factor-21 levels in patients with type 2 diabetes mellitus. European Journal of Endocrinology 2009161 391-395. (doi:10.1530/EJE-09-0335)

69 Samson SL, Sathyanarayana P, Jogi M, Gonzalez EV, Gutierrez A, Krishnamurthy R, Muthupillai R, Chan L \& Bajaj M. Exenatide decreases hepatic fibroblast growth factor 21 resistance in nonalcoholic fatty liver disease in a mouse model of obesity and in a randomised controlled trial. Diabetologia 2011 54 3093-3100. (doi:10.1007/s00125-011-2317-z)

70 Wang B, Yang G, Yang M, Liao Y, Li Z, Boden G \& Li L. Mitiglinide treatment may decreases plasma fibroblast growth factor-21 levels in individuals with new-onset T2DM. Cytokine 201257 300-303. (doi:10.1016/j.cyto.2011.11.002)

71 Yang M, Dong J, Liu H, Li L \& Yang G. Effects of short-term continuous subcutaneous insulin infusion on fasting plasma fibroblast growth factor-21 levels in patients with newly diagnosed type 2 diabetes mellitus. PLoS ONE 20116 e26359. (doi:10.1371/journal.pone.0026359)

72 Uebanso T, Taketani Y, Yamamoto H, Amo K, Ominami H, Arai H, Takei Y, Masuda M, Tanimura A, Harada N, YamanakaOkumura H \& Takeda E. Paradoxical regulation of human FGF21 by both fasting and feeding signals: is FGF21 a nutritional adaptation factor? PLoS ONE 20116 e22976. (doi:10.1371/ journal.pone.0022976)

73 Tyynismaa H, Raivio T, Hakkarainen A, Ortega-Alonso A, Lundbom N, Kaprio J, Rissanen A, Suomalainen A \& Pietilainen KH. Liver fat but not other adiposity measures influence circulating FGF21 levels in healthy young adult twins. Journal of Clinical Endocrinology and Metabolism 201196 E351-E355. (doi:10.1210/jc.2010-1326)

74 Zhang M, Xiong ZY, Zeng L, Wang YJ, Huang MJ \& An ZM. Plasma fibroblast growth factor- 21 and abdominal obesity. Sichuan Da Xue Хиe Bao Yi Xue Ban = Journal of Sichuan University. Medical Science Edition 201041 487-489, 522.

75 Yilmaz Y, Eren F, Yonal O, Kurt R, Aktas B, Celikel CA, Ozdogan O, Imeryuz N, Kalayci C \& Avsar E. Increased serum FGF21 levels in patients with nonalcoholic fatty liver disease. European Journal of Clinical Investigation 201040 887-892. (doi:10.1111/j.13652362.2010.02338.x)

76 Li H, Fang Q, Gao F, Fan J, Zhou J, Wang X, Zhang H, Pan X, Bao Y, Xiang K, Xu A \& Jia W. Fibroblast growth factor 21 levels are increased in nonalcoholic fatty liver disease patients and are correlated with hepatic triglyceride. Journal of Hepatology 201053 934-940. (doi:10.1016/j.jhep.2010.05.018)

77 Yan H, Xia M, Chang X, Xu Q, Bian H, Zeng M, Rao S, Yao X, Tu Y, Jia W \& Gao X. Circulating fibroblast growth factor 21 levels are closely associated with hepatic fat content: a cross-sectional study. PLOS ONE 20116 e24895. (doi:10.1371/journal.pone.0024895)

78 Mai K, Schwarz F, Bobbert T, Andres J. Assmann A, Pfeiffer AF \& Spranger J. Relation between fibroblast growth factor-21, adiposity, metabolism, and weight reduction. Metabolism 2011 60 306-311. (doi:10.1016/j.metabol.2010.02.016)

79 Woelnerhanssen B, Peterli R, Steinert RE, Peters T, Borbély Y \& Beglinger C. Effects of postbariatric surgery weight loss on adipokines and metabolic parameters: comparison of laparoscopic 
Roux-en-Y gastric bypass and laparoscopic sleeve gastrectomy - a prospective randomized trial. Surgery for Obesity and Related Diseases 20117 561-568. (doi:10.1016/j.soard.2011.01.044)

80 Dostalova I, Kavalkova P, Haluzikova D, Lacinova Z, Mraz M, Papezova H \& Haluzik M. Plasma concentrations of fibroblast growth factors 19 and 21 in patients with anorexia nervosa. Journal of Clinical Endocrinology and Metabolism 2008933627 3632. (doi:10.1210/jc.2008-0746)

81 Stein S, Bachmann A, Lossner U, Kratzsch J, Bluher M, Stumvoll M \& Fasshauer M. Serum levels of the adipokine FGF21 depend on renal function. Diabetes Care 200932 126-128. (doi:10.2337/ dc08-1054)

82 Han SH, Choi SH, Cho BJ, Lee Y, Lim S, Park YJ, Moon MK, Lee HK, Kang SW, Han DS, Kim YB, Jang HC \& Park KS. Serum fibroblast growth factor-21 concentration is associated with residual renal function and insulin resistance in end-stage renal disease patients receiving long-term peritoneal dialysis. Metabolism: Clinical and Experimental 201059 1656-1662. (doi:10.1016/j.metabol. 2010.03.018)

83 Lin Z, Zhou Z, Liu Y, Gong Q, Yan X, Xiao J, Wang X, Lin S, Feng W \& Li X. Circulating FGF21 levels are progressively increased from the early to end stages of chronic kidney diseases and are associated with renal function in Chinese. PLoS ONE 20116 e18398. (doi:10.1371/journal.pone.0018398)

84 Crasto C, Semba RD, Sun K \& Ferrucci L. Serum fibroblast growth factor 21 is associated with renal function and chronic kidney disease in community-dwelling adults. Journal of the American Geriatrics Society 201260 792-793. (doi:10.1111/j.1532-5415. 2011.03879.x)

85 Kharitonenkov A \& Shanafelt AB. Fibroblast growth factor- 21 as a therapeutic agent for metabolic diseases. BioDrugs: Clinical Immunotherapeutics, Biopharmaceuticals and Gene Therapy 2008 22 37-44. (doi:10.2165/00063030-200822010-00004)
86 Dostalova I, Haluzikova D \& Haluzik M. Fibroblast growth factor 21: a novel metabolic regulator with potential therapeutic properties in obesity/type 2 diabetes mellitus. Physiological Research/Academia Scientiarum Bohemoslovaca 200958 1-7.

87 Huang Z, Wang H, Lu M, Sun C, Wu X, Tan Y, Ye C, Zhu G, Wang X, Cai L \& Li X. A better anti-diabetic recombinant human fibroblast growth factor 21 (rhFGF21) modified with polyethylene glycol. PLOS ONE 20116 e20669. (doi:10.1371/journal.pone. 0020669)

88 Wu AL, Kolumam G, Stawicki S, Chen Y, Li J, Zavala-Solorio J, Phamluong K, Feng B, Li L, Marsters S, Kates L, van Bruggen N, Leabman M, Wong A, West D, Stern H, Luis E, Kim HS, Yansura D, Peterson AS, Filvaroff E, Wu Y \& Sonoda J. Amelioration of type 2 diabetes by antibody-mediated activation of fibroblast growth factor receptor 1. Science Translational Medicine 20113113 ra126. (doi:10.1126/scitranslmed.3002669)

89 Zhao Y, Dunbar JD \& Kharitonenkov A. FGF21 as a therapeutic reagent. Advances in Experimental Medicine and Biology $2012 \mathbf{7 2 8}$ 214-228. (doi:10.1007/978-1-4614-0887-1_14)

$90 \mathrm{Mu}$ J, Pinkstaff J, Li Z, Skidmore L, Li N, Myler H, Dallas-Yang Q, Putnam AM, Yao J, Bussell S, Wu M, Norman TC, Rodriguez CG, Kimmel B, Metzger JM, Manibusan A, Lee D, Zaller DM, Zhang BB, DiMarchi RD, Berger JP \& Axelrod DW. FGF21 analogs of sustained action enabled by orthogonal biosynthesis demonstrate enhanced antidiabetic pharmacology in rodents. Diabetes $201261505-$ 512. (doi:10.2337/db11-0838)

Received 26 April 2012

Revised version received 24 June 2012

Accepted 27 June 2012 